This item was submitted to Loughborough's Institutional Repository (https://dspace.lboro.ac.uk/) by the author and is made available under the following Creative Commons Licence conditions.

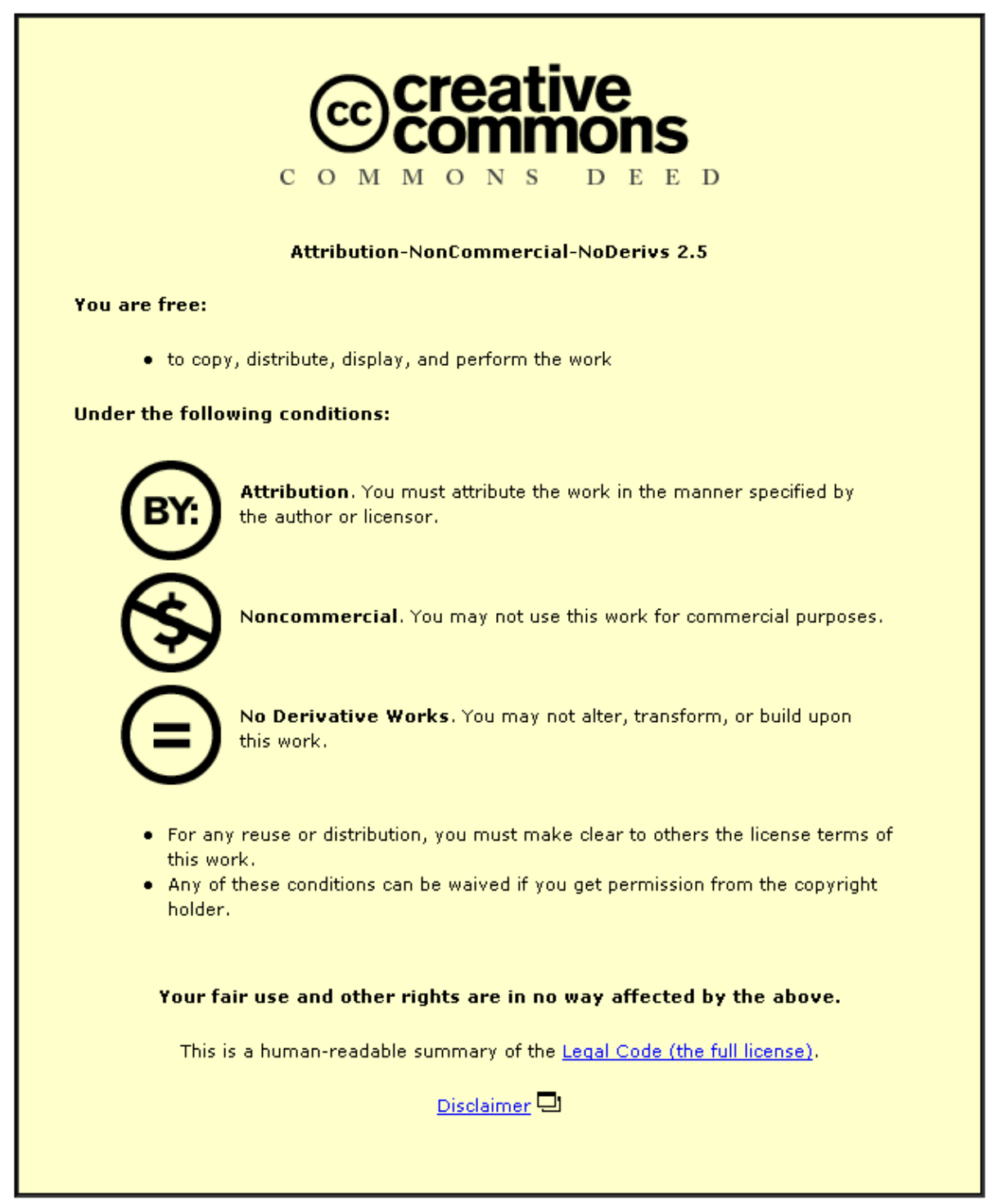

For the full text of this licence, please go to: http://creativecommons.org/licenses/by-nc-nd/2.5/ 


\title{
Long term Effect of Sulfate Ions and Associated Cation Type on Chloride- Induced Reinforcement Corrosion in Portland Cement Concretes
}

\author{
H. A. F. Dehwah*, M. Maslehuddin* and S. A. Austin** \\ * King Fahd University of Petroleum and Minerals, Dhahran 31261, Saudi Arabia \\ ** Loughborough University, Loughborough LE11 3TU, UK
}

\begin{abstract}
This paper reports the influence of sulfate concentration on chloride-induced reinforcement corrosion in Portland cement concretes (with $\mathrm{C}_{3} \mathrm{~A}$ varying from 3.6 to 9.65\%). The concrete specimens were exposed to mixed chloride and sulfate solutions for a period of 1200 days. The chloride was fixed at $5 \% \mathrm{NaCl}$ for all solutions, while the sulfate concentration was varied to represent that typical of sulfate-bearing soil and ground water. The study included an assessment of the effect of cation type associated with sulfate ions, namely $\mathrm{Na}^{+}$and $\mathrm{Mg}^{++}$, on chlorideinduced reinforcement corrosion, an important factor that has received little attention. Reinforcement corrosion was evaluated by measuring corrosion potentials and corrosion current density at regular intervals. The results indicate that the presence of sulfate ions in the chloride solution did not influence the time to initiation of chloride-induced reinforcement corrosion, but the rate of corrosion increased with increasing sulfate concentration. Further, the rate of chloride-induced reinforcement corrosion in the concrete specimens exposed to sodium chloride plus magnesium sulfate solutions was more than that in the specimens exposed to sodium chloride plus sodium sulfate solutions.
\end{abstract}

Keywords: Chloride-induced reinforcement corrosion, Sulfate cation, Sulfate concentration. 


\section{Introduction}

The low durability of reinforced concrete structures is of major concern to the construction industry throughout the world. The deterioration of concrete structures in temperate climatic conditions, as in Europe and North America, is mainly attributed to reinforcement corrosion that is caused by ingress of deicer salts or carbonation. Insufficient concrete cover over reinforcing steel and/or poor quality concrete accelerates the deterioration processes. Accelerated deterioration of reinforced concrete structures is also noted in the Arabian Gulf. The environmental and geomorphical conditions in the coastal areas of the Arabian Gulf contribute to a reduction in the useful service-life of concrete structures in this region, particularly the contamination of soil and ground water with chloride and sulfate salts. The daily and seasonal variations in the temperature and the humidity accelerate the rate of deterioration. The ambient temperature in the Arabian Gulf is high (40 to $45^{\circ} \mathrm{C}$ ) compared to that noted in the USA or Europe (15 to $\left.25^{\circ} \mathrm{C}\right)$. The direct solar radiation effect raises the temperature at the concrete surface to as high as 70 to $80^{\circ} \mathrm{C}$. This thermal effect influences the over all mechanisms of concrete deterioration processes, such as reinforcement corrosion, sulfate attack, salt weathering, and shrinkage and thermal cracking. Further, the rate of reinforcement corrosion increases rapidly with increasing ambient temperature.

Chloride ions are considered to be the primary cause of reinforcement corrosion (outweighing that due to carbonation) and the rate of corrosion is strongly influenced by environmental factors and concrete properties, such as permeability, type of cement, intensity of cracks, and concrete cover. Chlorides are contributed to 
the concrete by the admixtures, aggregates and/or mixing and curing water. Alternatively, they may penetrate the hardened concrete from the external environment, such as seawater, soil and groundwater that contain sulfate and chloride salts.

The precise role of sulfate ions on the mechanisms of chloride-induced reinforcement corrosion is not known. The conjoint presence of chloride and sulfate ions may significantly affect reinforcement corrosion. Limited data developed by AlAmoudi et al. [1-3] indicated that sulfate ions significantly influence the mechanism of chloride-induced reinforcement corrosion. In these studies [1-3] only two concentrations of sulfate ions (0.55 and 2.1\%) were investigated. The required concentrations of sulfate ions were obtained by mixing equivalent quantities of sodium sulfate and magnesium sulfate salts. Due to this mixing, the effect of cation type associated with the sulfate ions on reinforcement corrosion could not be evaluated.

This study was conducted to assess the effect of sulfate concentration and the associated cation type on chloride-induced reinforcement corrosion in concretes prepared with Portland cements (ordinary and sulfate resisting).

\section{Experimental Program}

\subsection{Materials and Specimen Preparation}

Reinforced concrete specimens were prepared using two ordinary Portland cements (OPC-A; $\mathrm{C}_{3} \mathrm{~A}: 8.5 \%$ and $\mathrm{OPC}-\mathrm{B} ; \mathrm{C}_{3} \mathrm{~A}$ : 9.65\%), and one sulfate-resisting Portland cement (SRPC; $\mathrm{C}_{3} \mathrm{~A}: 3.6 \%$ ). The chemical composition of the cements is shown in Table 1. 
The concrete mixtures were prepared with an effective water-cement ratio of 0.45 and total cement content of $350 \mathrm{~kg} / \mathrm{m}^{3}$. Crushed dolomitic limestone with a specific gravity of 2.43 and absorption of $3 \%$ was used as coarse aggregate and dune sand with a specific gravity of 2.53 and absorption of $0.57 \%$ was used as fine aggregate. The coarse and fine aggregates were washed to remove salts, dust and other fine particles. The volume of water in each mix was adjusted to compensate for the absorption of coarse and fine aggregates.

Reinforced concrete specimens, $75 \mathrm{~mm}$ in diameter and $150 \mathrm{~mm}$ high, with a single $12 \mathrm{~mm}$ diameter steel bar centered in the middle were prepared. An effective cover of $25 \mathrm{~mm}$ was provided at the bottom of the specimen. The steel bars were cleaned and coated with cement paste followed by an epoxy coating at the concreteair interface and at the bottom of the bar to avoid crevice corrosion at these locations. The steel bars were cleaned mechanically with a silicon carbide paper, wherever necessary, and degreased with acetone prior to casting in concrete.

The concrete ingredients were mixed in a mechanical mixer and placed in the moulds in two layers by consolidation on a vibrating table. After casting, the specimens were covered with polyethylene sheets and allowed to cure in the laboratory temperature for 24 hours. They were then demolded and cured in potable water maintained at $25{ }^{\circ} \mathrm{C}$ for 28 days. After this curing period, the specimens were dried by keeping them at room temperature for one week and then placed in plastic containers containing the test solutions.

\subsection{Exposure Solutions}

The concrete specimens were exposed to varying sulfate concentrations as detailed in Table 2. All the exposure solutions contained $5 \% \mathrm{NaCl}$ and varying 
concentrations of sodium or magnesium sulfate. The $5 \% \mathrm{NaCl}$ solution used in this study represents the chloride concentration in the seawater. The sulfate concentration was varied from 0 to $4 \%$ to systematically evaluate the effect of these ions on chloride-induced reinforcement corrosion. Further, the $4 \% \mathrm{SO}_{4}^{--}$is representative of the sulfate concentration in sabkha soils. Three reinforced concrete specimens from each concrete mix were placed in the selected exposure solution. Reinforced concrete specimens were partially immersed in the test solution. The level of the solution was adjusted, so that only 85 to $90 \mathrm{~mm}$ of the bottom of the specimens was in the solution. The chloride and sulfate concentration in the solutions was monitored and adjusted every two weeks.

\subsection{Monitoring of Reinforcement Corrosion}

Reinforcement corrosion was evaluated by measuring corrosion potentials and corrosion current density $\left(\mathrm{I}_{\text {corr }}\right)$. The corrosion potentials provide information on the time to initiation of reinforcement corrosion under laboratory conditions, while the corrosion current density provides information on the rate of reinforcement corrosion. These two components together constitute the service life model suggested by Tutti [4]. The corrosion potentials were measured using a saturated calomel reference electrode (SCE) and a high impedance voltmeter.

The corrosion current density was measured using the linear polarization resistance method (LPRM). Steel was polarized to $\pm 20 \mathrm{mV}$ of the corrosion potential at a scan rate of $0.1 \mathrm{mV} / \mathrm{s}$ utilizing a Potentiostat/Galvanostat. Corrosion current density was then calculated using the Stern-Geary formula [5]:

$$
\mathrm{I}_{\text {corr }}=\mathrm{B} / \mathrm{R}_{\mathrm{p}}
$$


Where: $I_{\text {corr }}=$ corrosion current density, $\mu \mathrm{A} / \mathrm{cm}^{2}$

$\mathrm{R}_{\mathrm{p}}=$ polarization resistance, $\mathrm{K} \Omega \cdot \mathrm{cm}^{2}$

$\mathrm{B}=\frac{\beta_{\mathrm{a}}^{*} \beta_{\mathrm{c}}}{2 \cdot 3\left(\beta_{\mathrm{a}}+\beta_{\mathrm{c}}\right)}$

Where: $\beta_{\mathrm{a}}$ and $\beta_{\mathrm{C}}$ are the anodic and cathodic Tafel constants, mV/decade, respectively.

The Tafel constants are normally obtained by polarizing the steel to $\pm 250 \mathrm{mV}$ of the corrosion potential (Tafel plot). However, in the absence of sufficient data on $\beta_{\mathrm{a}}$ and $\beta_{\mathrm{C}}$, a value of $\mathrm{B}$ equal to $26 \mathrm{mV}$ for steel in active condition and $52 \mathrm{mV}$ for steel in passive condition is used to calculate the corrosion current density [6]. In another study, Dehwah et al. [7] conducted potentiodynamic studies on concrete specimens and the results indicated that the Tafel constants are approximately $120 \mathrm{mV} /$ decade. Lambert et al. [8] reported a good correlation between corrosion rate determined using these values and the gravimetric weight loss method. In view of the aforesaid findings, Tafel constants of $120 \mathrm{mV}$ were adopted for the calculation of corrosion current density.

\section{Results}

\subsection{Effect of Chloride-Sulfate Exposure on Corrosion Initiation}

The corrosion potentials on steel in the SRPC concrete specimens exposed to 5\% $\mathrm{NaCl}$ solution, admixed with $0,1,2.5$ and $4 \% \mathrm{SO}^{--}$, derived from sodium sulfate, are depicted in Figure 1. Initially, the corrosion potentials were high (less negative) and decreased with the period of exposure. However, after 180 days of exposure, the corrosion potentials stabilized in all the specimens. Figure 2 shows the corrosion 
potentials in the SRPC concrete specimens exposed to sodium chloride solution admixed with magnesium sulfate. In these specimens also the corrosion potentials were high in the initial period of exposure but then decreased almost linearly with the period of exposure.

The corrosion potentials on steel in the OPC-A $\left(\mathrm{C}_{3} \mathrm{~A}: 8.5 \%\right)$ concrete specimens exposed to sodium chloride solution admixed with sodium or magnesium sulfate, are plotted in Figures 3 and 4, respectively. The trends of these data are similar to that of the SRPC specimens except that the long-term trend is more stable with the magnesium sulfate. Figures 5 and 6 depict the corrosion potentials on steel bars in the OPC-B $\left(\mathrm{C}_{3} \mathrm{~A}: 9.65 \%\right)$ concrete specimens exposed to sodium chloride solution admixed with sodium or magnesium sulfate, respectively. In these specimens also the corrosion potentials decreased with time and were stable after about 150 days and the trend of these data is similar to that noted in the OPC-A concrete specimens exposed to similar solutions.

The time-corrosion potential curves, discussed in Figures 1 through 6, were used to evaluate the time to initiation of reinforcement corrosion, based on the ASTM C876 criterion of $-270 \mathrm{mV}$ SCE. These values are summarized in Table 3 . The timeto-initiation of reinforcement corrosion did not vary significantly with the cation type and the sulfate concentration. However, the time-to-initiation of reinforcement corrosion was influenced by the type of cement, namely the $\mathrm{C}_{3} \mathrm{~A}$ content. Reinforcement corrosion in SRPC concrete specimens $\left(\mathrm{C}_{3} \mathrm{~A}\right.$ : 3.6\%) occurred earlier than in the ordinary Portland cement concrete specimens. The delay in corrosion initiation with increasing $\mathrm{C}_{3} \mathrm{~A}$ content may be attributed to the complexation of 
chloride ions with the $\mathrm{C}_{3} \mathrm{~A}$. The similarity of the results for the two Portland cements demonstrates the repeatability of the trends observed.

\subsection{Effect of Chloride-Sulfate Exposure on Corrosion Current Density}

The corrosion current density ( $\mathrm{I}_{\text {corr }}$ ) on the steel bars in the SRPC concrete specimens exposed to $5 \% \mathrm{NaCl}$ solutions admixed with $0,1,2.5$ and $4 \% \mathrm{SO}_{4}^{--}$, derived from sodium sulfate, is depicted in Figure 7. The $\mathrm{I}_{\text {corr }}$ increased almost linearly with the period of exposure. These values were very low and similar in all the specimens in the initial stages of exposure of up to 90 days. However, after this time, the $\mathrm{I}_{\mathrm{corr}}$ on steel in the concrete specimens exposed to sodium chloride plus sodium sulfate solutions was more than that in the specimens exposed to sodium chloride solution.

Figure 8 shows the variation of $\mathrm{I}_{\text {corr }}$ with time in the SRPC concrete specimens exposed to $\mathrm{NaCl}$ solution admixed with magnesium sulfate. Almost a linear increase in the $\mathrm{I}_{\text {corr }}$ values, with the period of exposure, was observed in all the specimens. Initially, the values were low and approximately the same in all the specimens. However, they increased with time and after 160 days of exposure, the $I_{\text {corr }}$ on steel in the concrete specimens exposed to sodium chloride plus magnesium sulfate solution was significantly greater than that in the specimens exposed to only sodium chloride solution. Further, the $I_{\text {corr }}$ values increased with increasing magnesium sulfate concentration of up to 2.5\%. However, a slight decrease in the $\mathrm{I}_{\text {corr }}$ values were noted in the concrete specimens exposed to $4 \% \mathrm{SO}_{4}^{--}$. The latter may be attributed to the formation of magnesium hydroxide (brucite) which blocks the pores in the concrete specimens exposed to these solutions and decreases the diffusion of oxygen to the steel surface. 
Figures 9 and 10 depict the $\mathrm{I}_{\text {corr }}$ on steel in the OPC-A $\left(\mathrm{C}_{3} \mathrm{~A}: 8.5 \%\right)$ and OPC-B $\left(\mathrm{C}_{3} \mathrm{~A}: 9.65 \%\right)$ concrete specimens exposed to sodium chloride plus sodium sulfate. The trend of these data was similar to that noted in the SRPC concrete specimens exposed to similar solutions.

Figures 11 and 12 depict the $\mathrm{I}_{\text {corr }}$ on steel in the OPC-A and OPC-B concrete specimens exposed to sodium sulfate solution, admixed with magnesium sulfate. The trend of these data was also similar to that noted in the SRPC concrete specimens exposed to similar solutions.

The $\mathrm{I}_{\text {corr }}$ on steel bars in the concrete specimens exposed to sodium chloride plus sodium or magnesium sulfate solutions are plotted against sulfate concentration in Figures 13 and 14 . The $\mathrm{I}_{\text {corr }}$ increased almost linearly with increasing concentration of sodium sulfate, with magnesium it increased up to $2.5 \% \mathrm{SO}_{4}{ }^{--}$, but then decreased slightly when the $\mathrm{SO}_{4}{ }^{--}$increased from 2.5 to $4 \%$.

The $\mathrm{I}_{\text {corr }}$ on steel in the concrete specimens exposed to sodium chloride plus sodium or magnesium sulfate is plotted against $\mathrm{C}_{3} \mathrm{~A}$ in Figures 15 and 16 . The $\mathrm{I}_{\text {corr }}$ values decreased with increasing $\mathrm{C}_{3} \mathrm{~A}$ content in cement with both types of cation, although the magnesium sulfate produced higher $\mathrm{I}_{\text {corr }}$ values.

\section{$4 \quad$ Discussion}

Corrosion of reinforcing steel is mainly attributed to chloride ions. It would be expected that the presence of sulfate ions would affect the mineralogical composition of hardened concrete and hence its corrosion-resisting characteristics. However, the precise role of sulfate ions in chloride-induced reinforcement corrosion is not very well investigated. The meager data available have indicated an increase in the 
corrosion activity in the concrete specimens exposed to chloride plus sulfate environments compared to specimens exposed to only chloride environments. Treadaway et al. [9] investigated the effect of adding chloride and sulfate ions to concrete on reinforcement corrosion in the SRPC concrete specimens. The results of that study indicated higher reinforcement corrosion in the specimens admixed with sodium chloride plus sodium sulfate compared to those specimens admixed with only sodium chloride.

Al-Amoudi and Maslehuddin [1] indicated that while the sulfate ions are hardly able to induce reinforcement corrosion it was significant in the concrete specimens exposed to sodium chloride plus sodium sulfate solution. Reinforcement corrosion increased two times when the sulfate concentration in the $15.7 \%$ chloride solution was increased from 0.55 to $2.1 \%$. An extension of this study [2] on plain and blended cements also indicated higher reinforcement corrosion in the specimens exposed to sodium chloride plus sodium sulfate than in the specimens exposed to only sodium chloride. Maslehuddin [10] indicated that the increase in reinforcement corrosion due to the addition of sulfate and chloride salts was 1.1 to 2.4 times that measured in the concrete specimens admixed with only sodium chloride.

As shown in Table 3, the data developed in the present study show that sulfate ions have little effect on the time to initiation of reinforcement corrosion. This may be attributed to the fact that corrosion initiation, when exposed to mixed chloride and sulfate environments, is predominantly governed by the relative diffusivity of these two ions. Several studies [11-15] have indicated that chloride ions diffuse much faster than sulfate ions into hardened cement paste. Oberholster [11] reported that the diffusion of chloride ions in concrete is generally 10 to 100 times faster than that of 
sulfate ions. Rio and Turriziani [12] indicated that the diffusion of $\mathrm{Cl}^{-}$in plain and blended cements was twice that of $\mathrm{SO}_{4}^{--}$. Stratfull [13] reported that concrete retained 14 times more chloride ions than sulfate ions. Barnes and Roy [14] reported that the diffusion rates of $\mathrm{SO}_{4}{ }^{--}$is two to five times that of $\mathrm{Na}^{+}$. Bakker [15] indicated that the diffusion of chloride ions is considerably faster than $\mathrm{SO}_{4}^{--}$and other cations, whilst Oberholster [11] reported that the diffusion coefficient of chloride ions in hardened cement pastes increases when they are associated with divalent ions compared to monovalent ions.

In the present study, the corrosion current density on steel in the concrete specimens exposed to chloride-sulfate environments was more than that in the specimens exposed to only chloride environments. Further, the $\mathrm{I}_{\text {corr }}$ increased with increasing sulfate concentration.

The increase in the $\mathrm{I}_{\mathrm{corr}}$ in the concrete specimens exposed to chloride plus sulfate solutions may be attributed to the following two factors:

1. an increase in the concentration of free chloride ions in the pore solution due to the concurrent presence of sulfate and chloride ions; and

2. a decrease in the electrical resistivity of concrete due to the conjoint presence of sulfate and chloride ions.

The combined presence of chloride and sulfate ions increases the concentration of free chloride ions in the pore solution. This increase in the free-chloride ion concentration is ascribed to the simultaneous reaction of $\mathrm{C}_{3} \mathrm{~A}$ with both chloride and sulfate ions. Chloride ions normally react with $\mathrm{C}_{3} \mathrm{~A}$ in cement to form an insoluble compound known as calcium chloro-aluminate hydrate $\left(\mathrm{C}_{3} \mathrm{~A} \cdot \mathrm{CaCl}_{2} \cdot 10 \mathrm{H}_{2} \mathrm{O}\right)$, also 
known as Friedel's salt. This chemical reaction reduces the quantity of free chloride ions in the pore solution thereby decreasing the chances of steel depassivation. When both chloride and sulfate ions are present, $\mathrm{C}_{3} \mathrm{~A}$ reacts concomitantly with both sulfate and chloride ions, as a result the proportion of chlorides bound is less than that when only chlorides are present.

The other factor that may contribute to an increase in the $\mathrm{I}_{\text {corr }}$, due to the conjoint presence of chloride and sulfate ions is the reduction in the electrical resistivity of concrete. The electrical resistivity of concrete specimens admixed with chloride plus sulfate salts is generally lower than that of specimens admixed with only chloride ions. Khan [16] indicated that the electrical resistivity of concrete specimens admixed with sodium chloride was 1.4 to 7 times that of specimens admixed with sodium chloride plus sodium sulfate. Since the electrical resistivity of concrete is one of the factors controlling the rate of reinforcement corrosion, it is apparent that a reduction in the electrical resistivity will lead to increased rate of corrosion. According to Polder [17] a relationship between the resistivity of concrete and the corrosion rate of reinforcement should be due to the electrochemical nature of the corrosion process. In the corrosion cell circuit, ionic transport between the anode and cathode is one of the rate controlling factors. Similarly, in Bazant's model [18] the corrosion rate is inversely proportional to the resistivity.

The data developed in the present study suggest that the presence of both chloride and sulfate ions does not influence the time to initiation of reinforcement corrosion. This trend was noted in both ordinary and sulfate resisting Portland cement concrete specimens when exposed to either sodium or magnesium sulfate solution admixed with sodium chloride. Such a behavior has also reported by Al-Amoudi et al. [1-2]. 
However, in these studies [1-2] the sulfate ions were provided by both sodium and magnesium sulfate salts, while in the present study, the individual effect of $\mathrm{Na}_{2} \mathrm{SO}_{4}$ and $\mathrm{MgSO}_{4}$ has been evaluated.

The data developed in the present study also indicate that the $\mathrm{I}_{\text {corr }}$ is influenced by the cation type associated with the sulfate ions, it being greater in the specimens exposed to $\mathrm{MgSO}_{4}$ than to $\mathrm{Na}_{2} \mathrm{SO}_{4}$. The $\mathrm{I}_{\text {corr }}$ increased with increasing concentration of sodium sulfate and magnesium sulfate. However, a marginal decrease in the $\mathrm{I}_{\text {corr }}$ was noted when the concentration of magnesium sulfate was increased from 2.5 to $4.0 \%$, which may be attributed to the formation of $\mathrm{Mg}(\mathrm{OH})_{2}$ [19-20] that blocks the pores in the concrete specimens exposed to these solutions and retards the diffusion of oxygen to the steel surface.

\section{Conclusions}

The presence of sulfate ions in chloride environments did not affect the timeto-initiation of reinforcement corrosion. The time-to-initiation of reinforcement corrosion in the ordinary Portland cement concrete specimens was marginally more than that in the sulfate-resisting Portland cement concrete specimens.

The corrosion current density ( $\left.\mathrm{I}_{\text {corr }}\right)$ increased with increasing sodium sulfate concentration. The $\mathrm{I}_{\text {corr }}$ in the concrete specimens exposed to sodium chloride plus sodium sulfates was 1.1 to 2.0 times that in the concrete specimens exposed to only sodium chloride solution. Similarly, the $\mathrm{I}_{\text {corr }}$ increased with increasing magnesium sulfate concentration of up to $2.5 \% \mathrm{SO}_{4}^{--}$. This increase was 1.1 to 2.2 times that in the specimens exposed to only sodium chloride. The $\mathrm{I}_{\text {corr }}$ in the concrete specimens exposed to $4 \% \mathrm{SO}_{4}^{--}\left(\mathrm{MgSO}_{4}\right)$ was marginally less than that in the specimens exposed to $2.5 \% \mathrm{SO}_{4}^{--}\left(\mathrm{MgSO}_{4}\right)$. 
The $\mathrm{I}_{\text {corr }}$ increased with increasing period of exposure and sulfate concentration and it was higher in the case of magnesium sulfate compared to sodium sulfate. The $\mathrm{I}_{\text {corr }}$ decreased with increasing $\mathrm{C}_{3} \mathrm{~A}$ content in cement. This behaviour may be attributed to increased chloride-binding by high $\mathrm{C}_{3} \mathrm{~A}$ cements which results in increased electrical resistivity in the ordinary Portland cements compared to sulfate resisting Portland cements.

\section{Acknowledgments}

The authors acknowledge the support provided by King Fahd University of Petroleum and Minerals, Dhahran, Saudi Arabia and the Department of Civil and Building Engineering, Loughborough University, UK.

\section{References}

1. Al-Amoudi, O. S. B. and Maslehuddin, M., "The Effect of Chloride and Sulfate Ions on Reinforcement Corrosion," Cement and Concrete Research, Vol. 23, No. 1, 1993, pp. 139-146.

2. Al-Amoudi, O. S. B., Rasheeduzzafar, Maslehuddin, M., and Abduljauwad, S. N.," Influence of Sulfate ions on Chloride Induced Reinforcement Corrosion in Portland and Blended Cement Concretes," Cement, Concretes, and Aggregates, Vol. 16, No. 1, June 1994, pp. 3-11.

3. Al-Amoudi, O. S. B., Abduljauwad, S. N., Rasheeduzzafar and Maslehuddin, M., "Effect of Chloride and Sulfate Contamination in Soils on Corrosion of Steel and Concrete," Transportation Research Record No. 1345, 1992, pp. 6773.

4. Tutti, K., Corrosion of Steel in Concrete, Research Report 4182, Swedish Cement and Concrete Research Institute, Stockholm, 1982.

5. Stern, M. and Geary, A. L., "Electrochemical Polarization, No. 1, Theoretical Analysis of the Shape of Polarization Curves," Journal of Electrochemical Society, Vol. 104, No. 1, Jan. 1957, p. 56.

6. Andrade, C., Castelo, V., Alonso, C. and Gonzalez, J. A., "Determination of the Corrosion Rate of Steel Embedded in Concrete," ASTM Special Technical Publication STP 906, Philadelphia, 1986, p. 43.

7. Dehwah, H. A. F., Basunbul, I.A., Maslehuddin, M., Al-Sulaimani, G.J., and Baluch, M., "Durability Performance of Repaired Reinforced Concrete Beams," , ACI Materials Journal, Vol.91 No.2 March-April 1994, pp.167172. 
8. Lambert, P., Page, C. L. and Vassie, P. R. W., "Investigations of Reinforcement Corrosion. 2. Electrochemical Monitoring of Steel in ChlorideContaminated Concrete," Materials and Structures, 24, 1991, pp. 351-358.

9. Treadaway, K. W. J., Page, C. L. and Macmillan, G. L., "The Prediction of Reinforcement Corrosion: From Laboratory Study to Exposure Trials," Durability of Construction Materials, J. C. Maso, Editor, Vol. 3, Chapman and Hall, London, 1987, pp. 1323-1329.

10. Maslehuddin, M., The Influence of Arabian Gulf Environment on Mechanisms of Reinforcement Corrosion, Ph.D. Thesis, Aston University, Birmingham, U.K, September, 1994.

11. Obserholster, R. E., "Pore Structure, Permeability and Diffusivity of Hardened Cement Paste and Concrete in Relation to Durability: Status and Prospects," Proceedings, 8th International Congress on the Chemistry of Cement, Rio Janeiro, Brazil, Sub-Theme 4.1, September 1986, pp. 323-335.

15.12. Rio, A., and Turriziani, R., Il Cemento, Vol. 80, No. 1, 1983, pp. 37-48.

16.13. Stratful, R. F., "Effect on Reinforced Concrete in Sodium Chloride and Sodium Sulfate Environments," Materials Protection, Vol. 3, No. 12,

14. Barnes, M. and Roy, D. M.,"Leaching of Salt Stones Containing Fly Ash and Slag," Internal Reports, 1985.

15. Bakker, R. F. M.,“Permeability of Blended Cement Concretes," ACI Special Publication SP-79, American Concrete Institute, Detroit, 1983, pp. 589-605. December 1964, pp. 74-80.

19.16. Khan, C. N. S. A., The Effect of Temperature and Salt contamination on Corrosion of Reinforcing Steel in OPC and Blended Cement Concretes, M.S. Thesis, King Fahd University of Petroleum and Minerals, Dhahran, August 1993.

20.17. Polder, R. B., "Test methods for on-site measurement of resistivity of Concrete - A RILEM TC-154 Technical Recommendation," Proceedings of a Special Technical Session on Near-Surface Testing for Strength and Durability of Concrete, Bercelona, Spain, 4-9 June 2000, pp. 139-154.

18. Bazant, Z., "Physical model for steel corrosion in Concrete Sea StructuresTheory and Application," Journal of Structural Division, ASCE, Vol. 105 (ST6), 1979, pp. 1137-1166.

19. Rasheeduzzafar, Al-Amoudi, O. S. B., Abduljauwad, S. N., and Maslehuddin, M., "Mechanisms of Magnesium-Sodium Sulfate Attack in Plain and Blended Cements, ASCE Journal of Materials in Civil Engineering, Vol. 6, No. 2, May 1994, pp. 201-222.

20. Cohen, M. D., and Bentur, A., "Durability of Portland Cement-Silica Fume Pastes in Magnesium Sulfate and Sodium Sulfate Solutions," ACI Materials 
Journal, Vol. 85, No. 3, May-June 1988, pp. 148-157. 


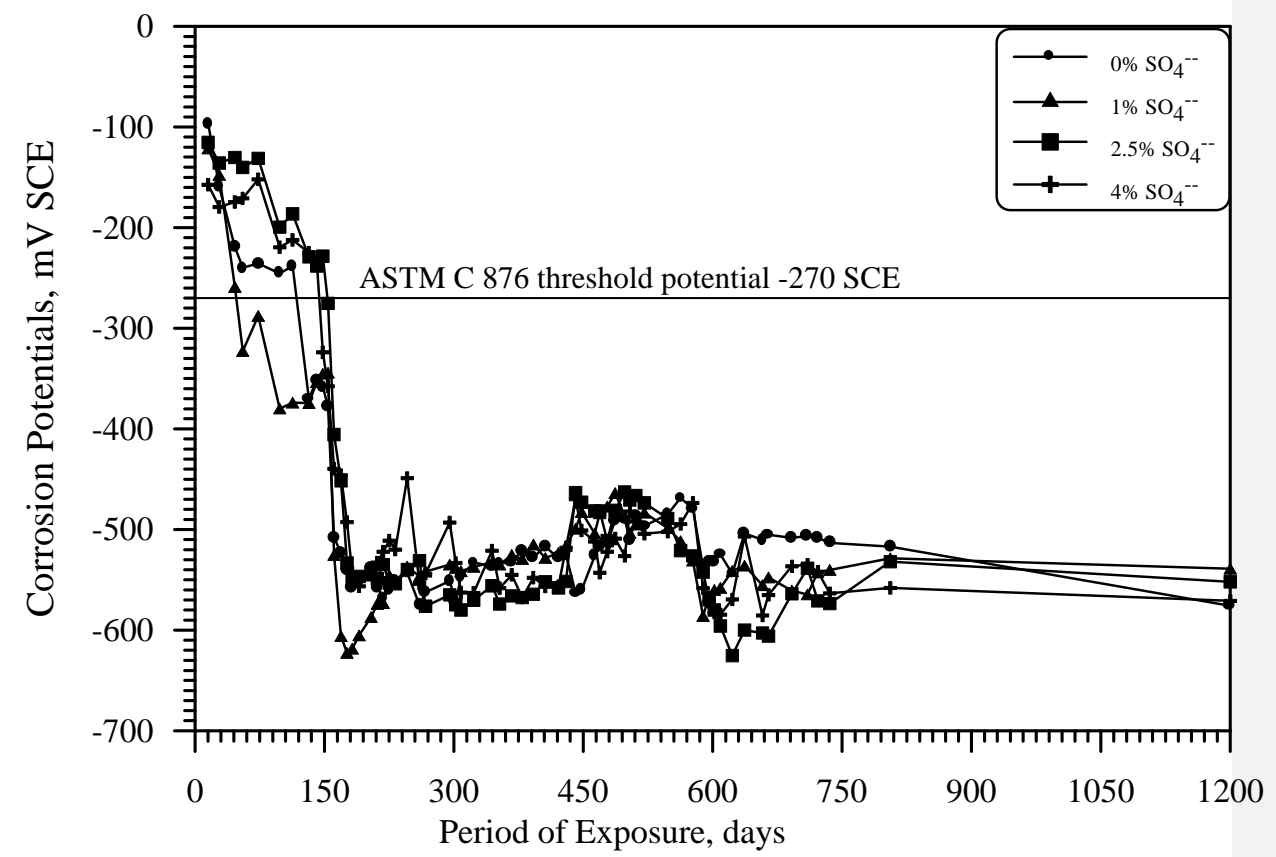

Figure 1: Corrosion potentials on steel bars in the SRPC concrete specimens exposed to $5 \% \mathrm{NaCl}$ plus sodium sulfate solution.

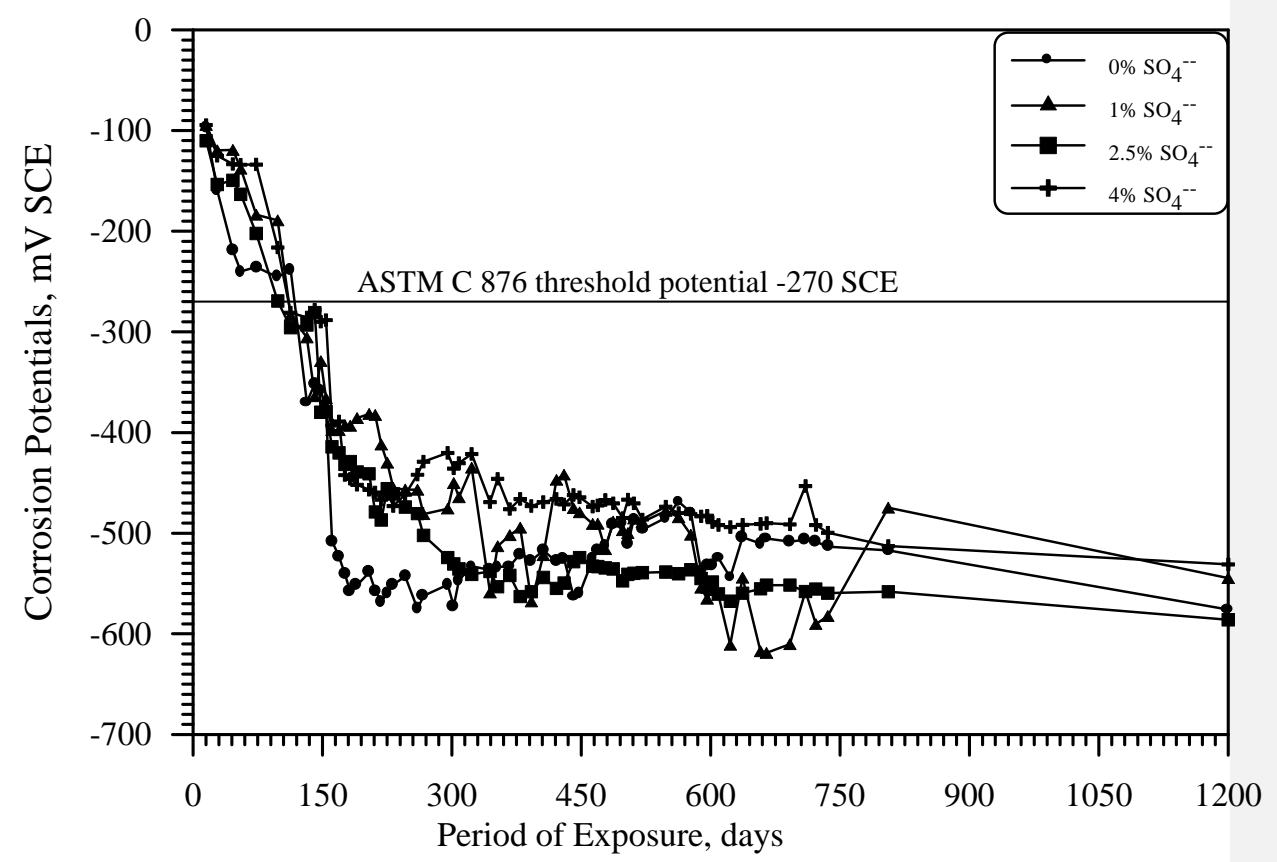

Figure 2: Corrosion potentials on steel bars in the SRPC concrete specimens exposed to $5 \% \mathrm{NaCl}$ plus magnesium sulfate solution. 


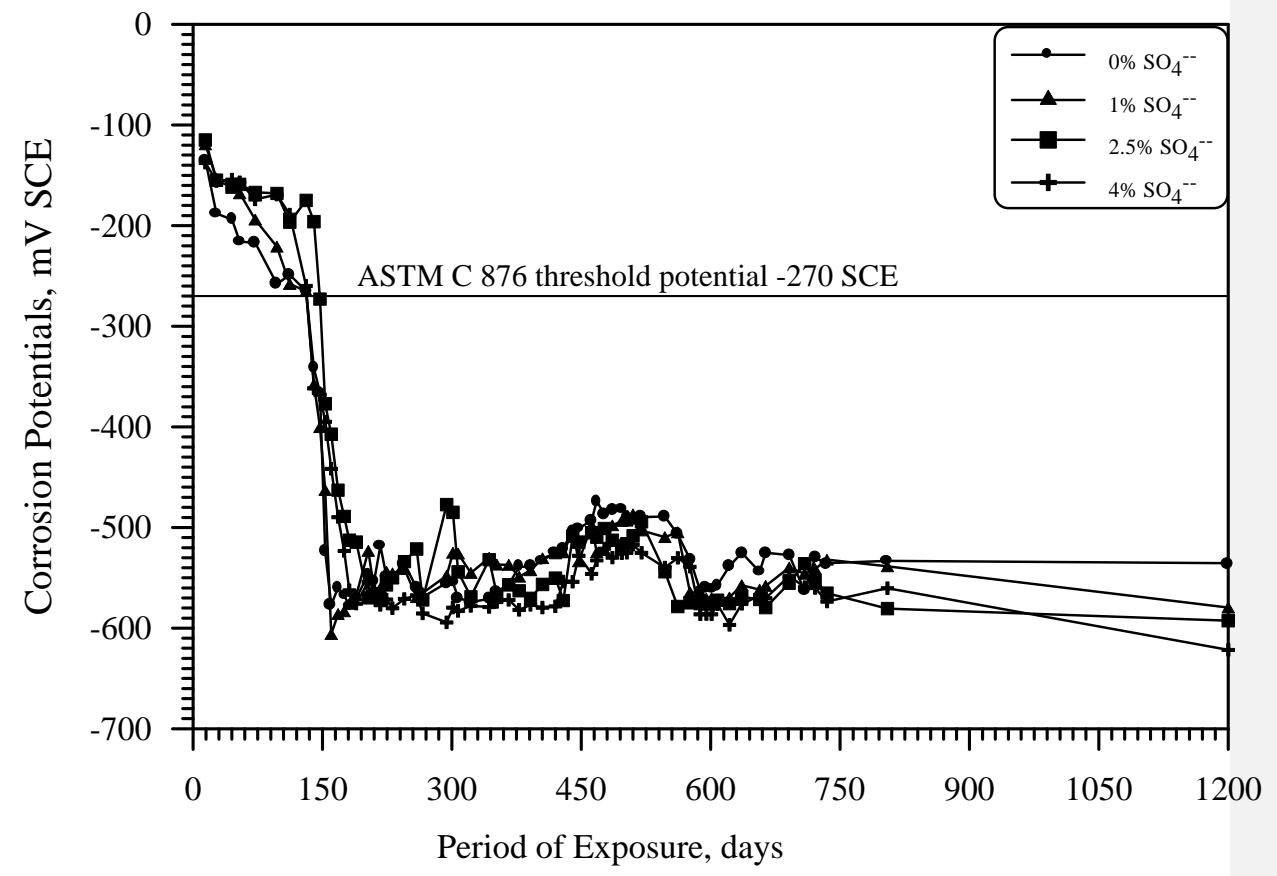

Figure 3: Corrosion potentials on steel bars in the OPC-A concrete specimens exposed to $5 \% \mathrm{NaCl}$ plus sodium sulfate solution.

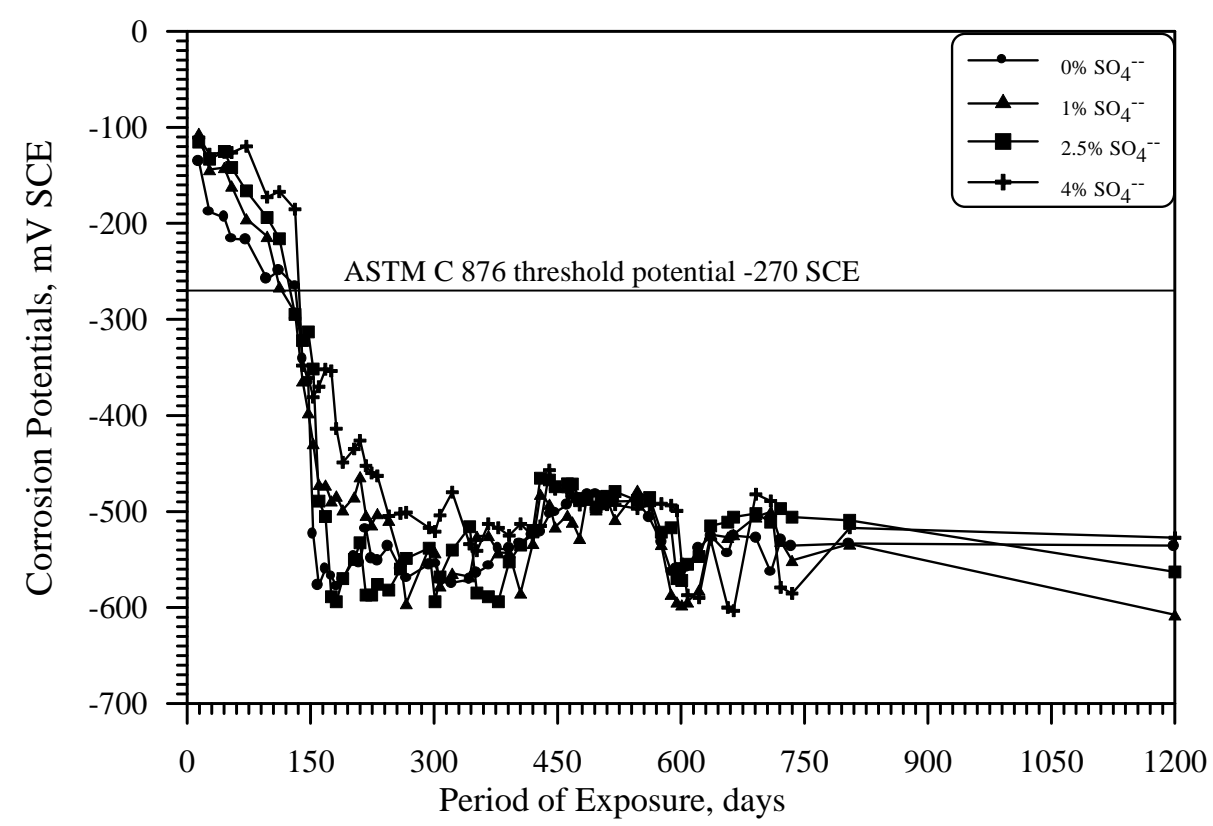

Figure 4: Corrosion potentials on steel bars in the OPC-A concrete specimens exposed to $5 \% \mathrm{NaCl}$ plus magnesium sulfate solution. 


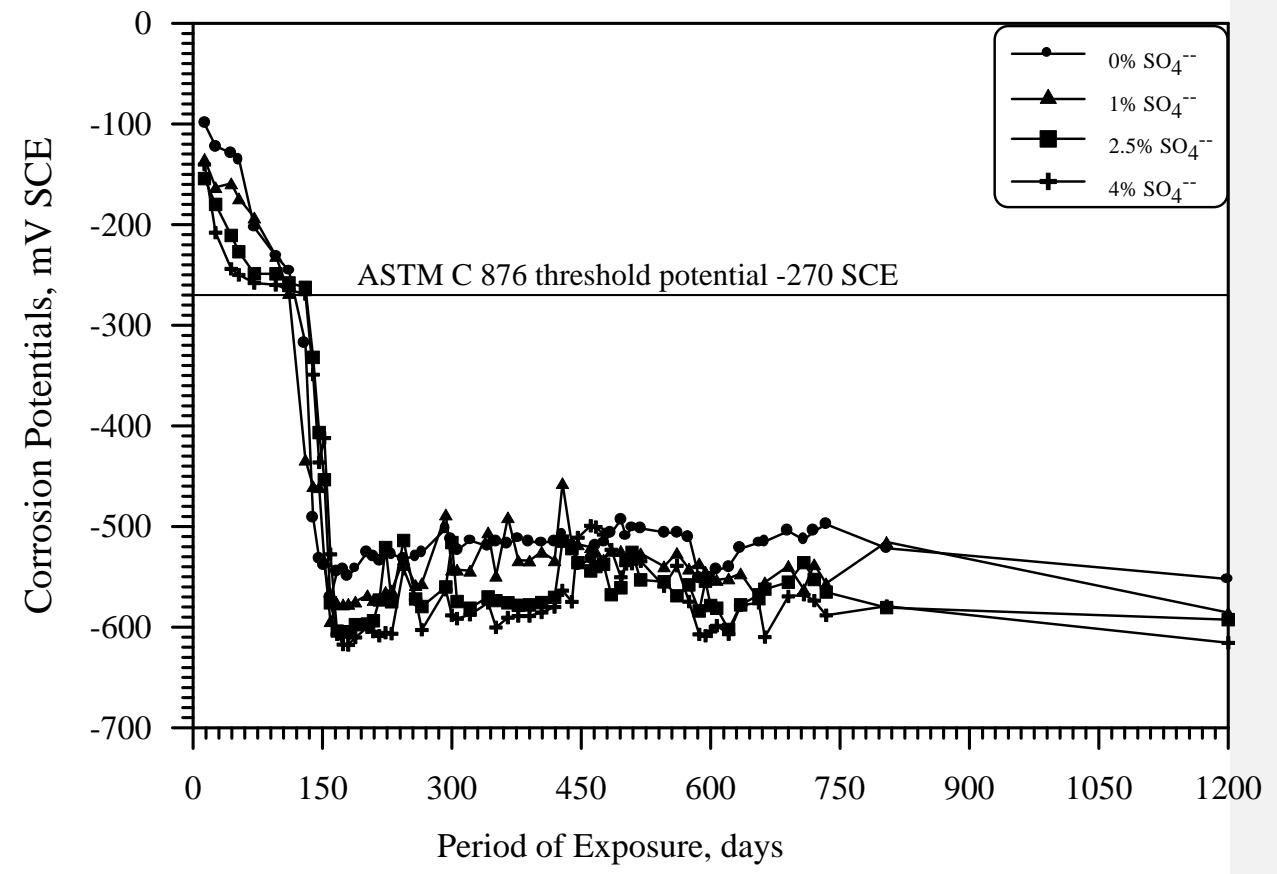

Figure 5: Corrosion potentials on steel bars in the OPC-B concrete specimens exposed to $5 \% \mathrm{NaCl}$ plus sodium sulfate solution.

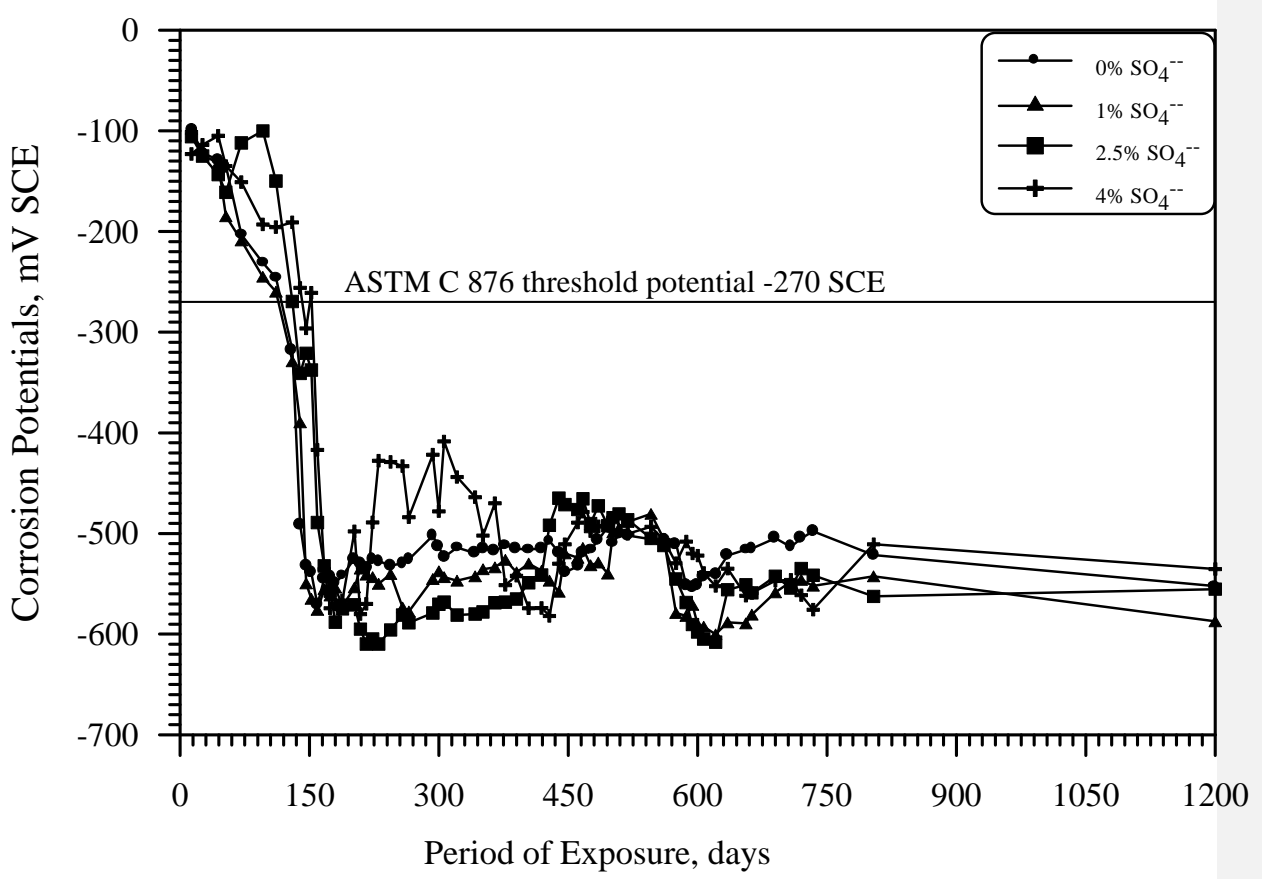

Figure 6: Corrosion potentials on steel bars in the OPC-B concrete specimens exposed to $5 \% \mathrm{NaCl}$ plus magnesium sulfate solution. 


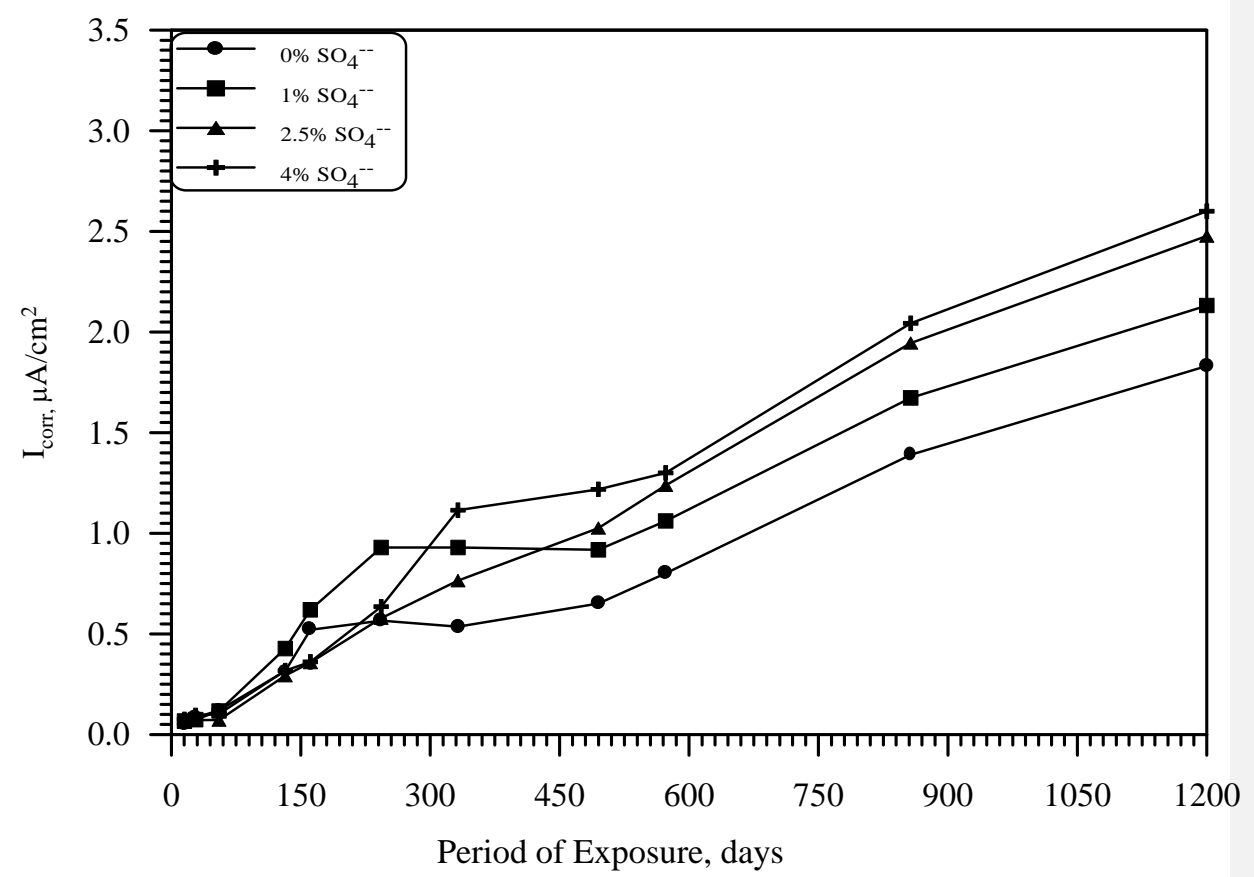

Figure 7: Corrosion current density on steel bars in the SRPC concrete specimens exposed to $5 \% \mathrm{NaCl}$ plus sodium sulfate solution.

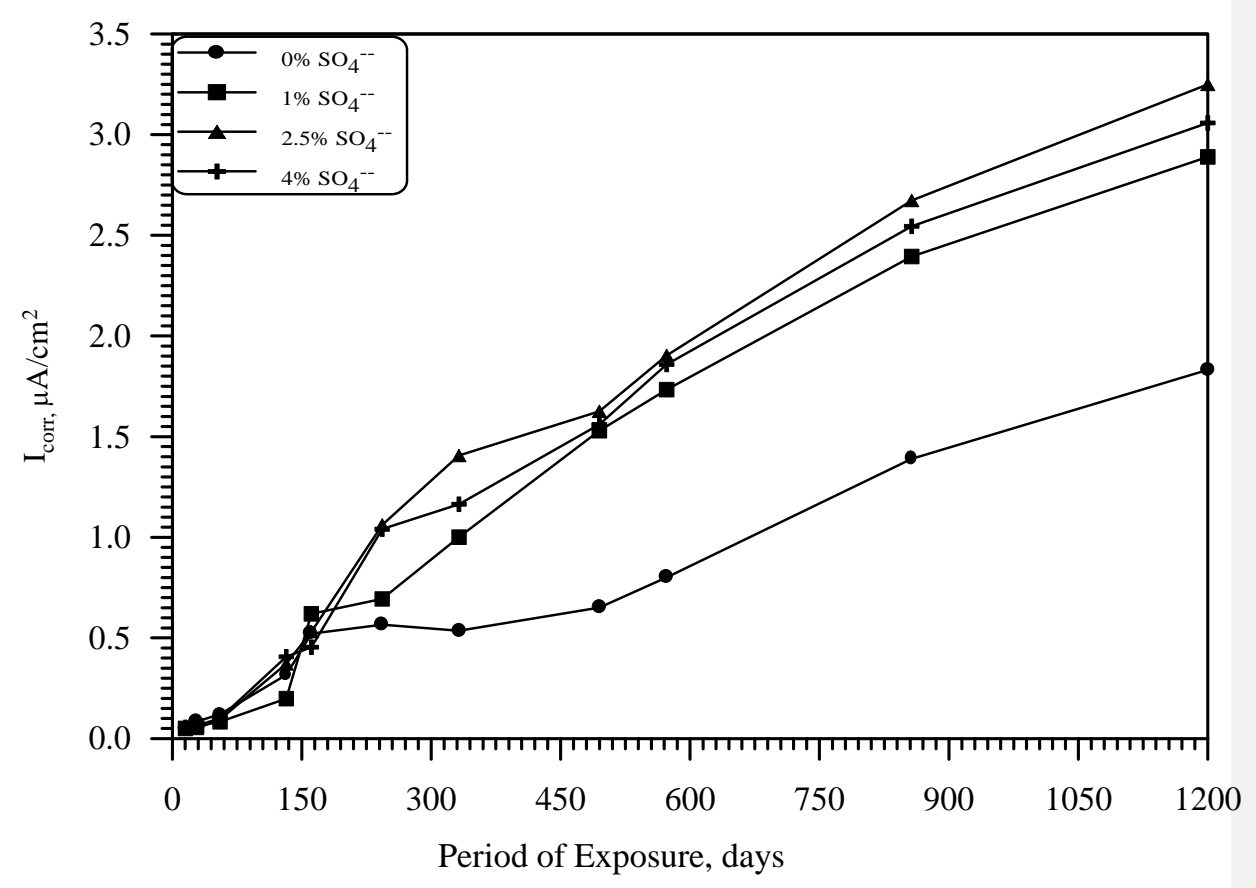

Figure 8: Corrosion current density on steel bars in the SRPC concrete specimens exposed to $5 \% \mathrm{NaCl}$ plus magnesium sulfate solution. 


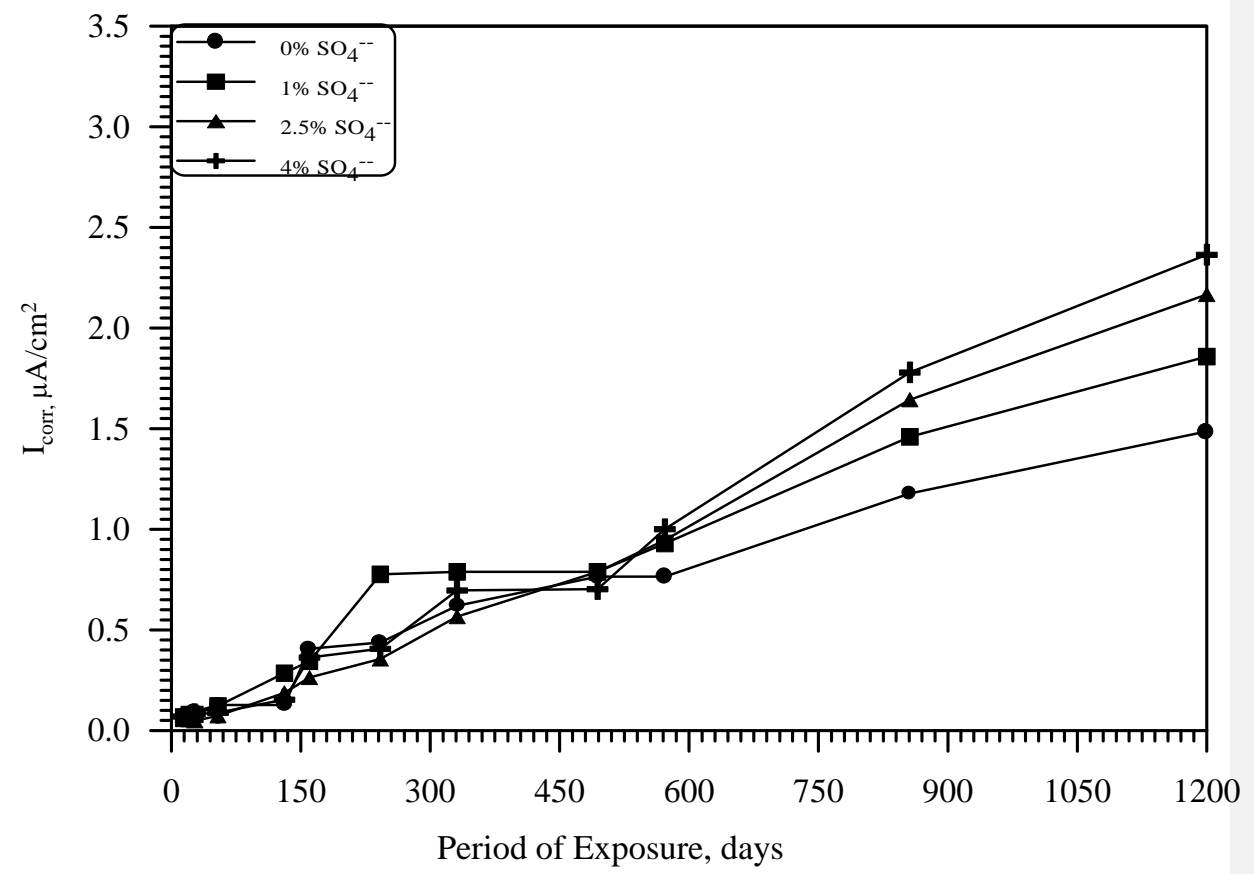

Figure 9: Corrosion current density on steel bars in the OPC-A concrete specimens exposed to $5 \% \mathrm{NaCl}$ plus sodium sulfate solution.

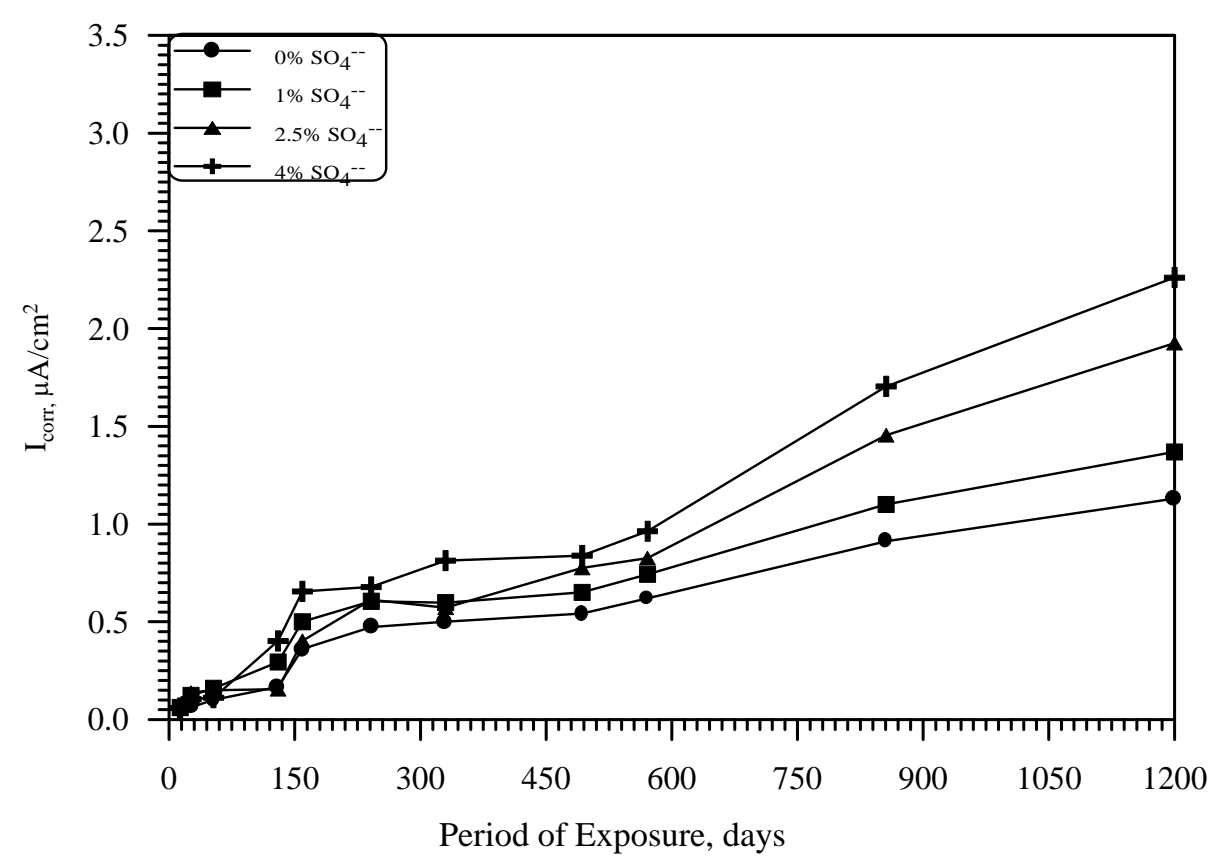

Figure 10: Corrosion current density on steel bars in the OPC-B concrete specimens exposed to $5 \% \mathrm{NaCl}$ plus sodium sulfate solution. 


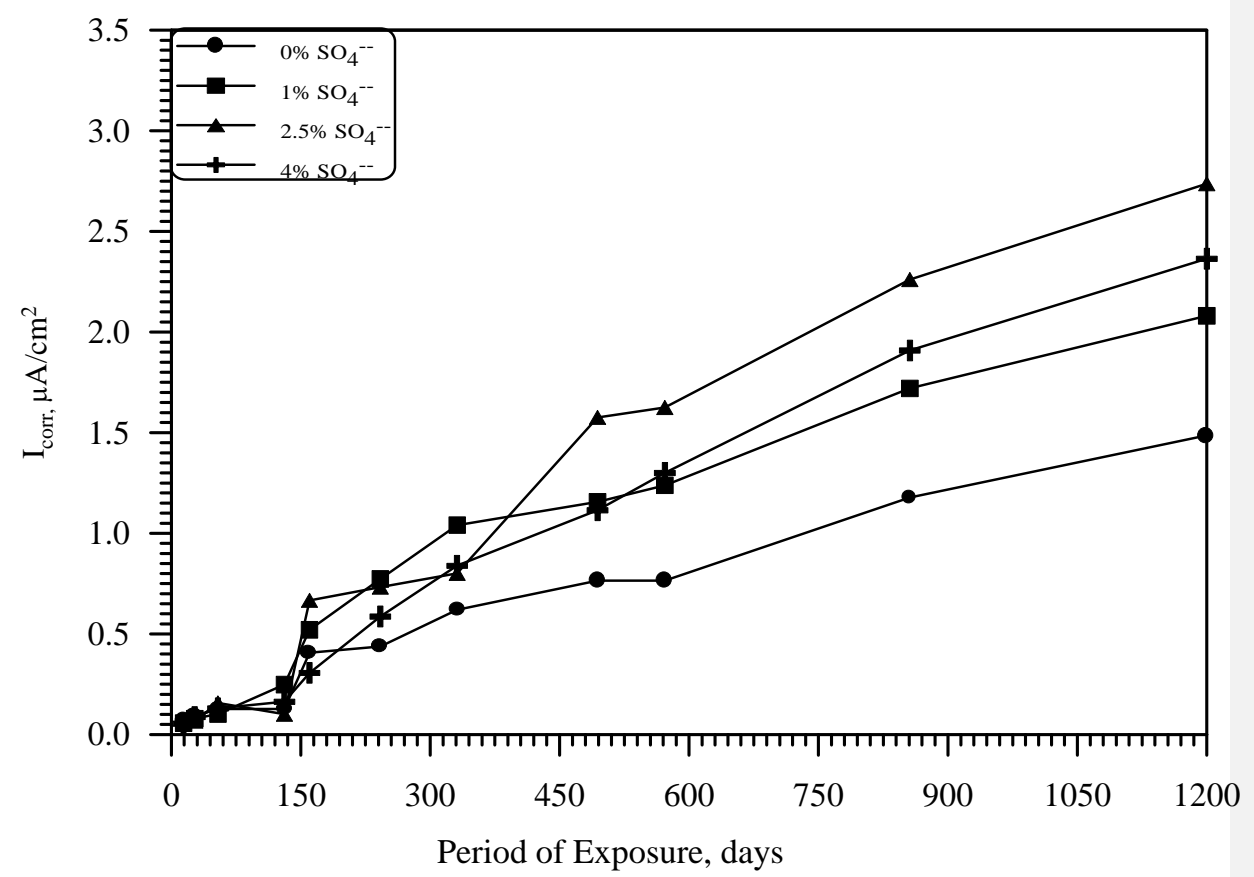

Figure 11: Corrosion current density on steel bars in the OPC-A concrete specimens exposed to $5 \% \mathrm{NaCl}$ plus magnesium sulfate solution.

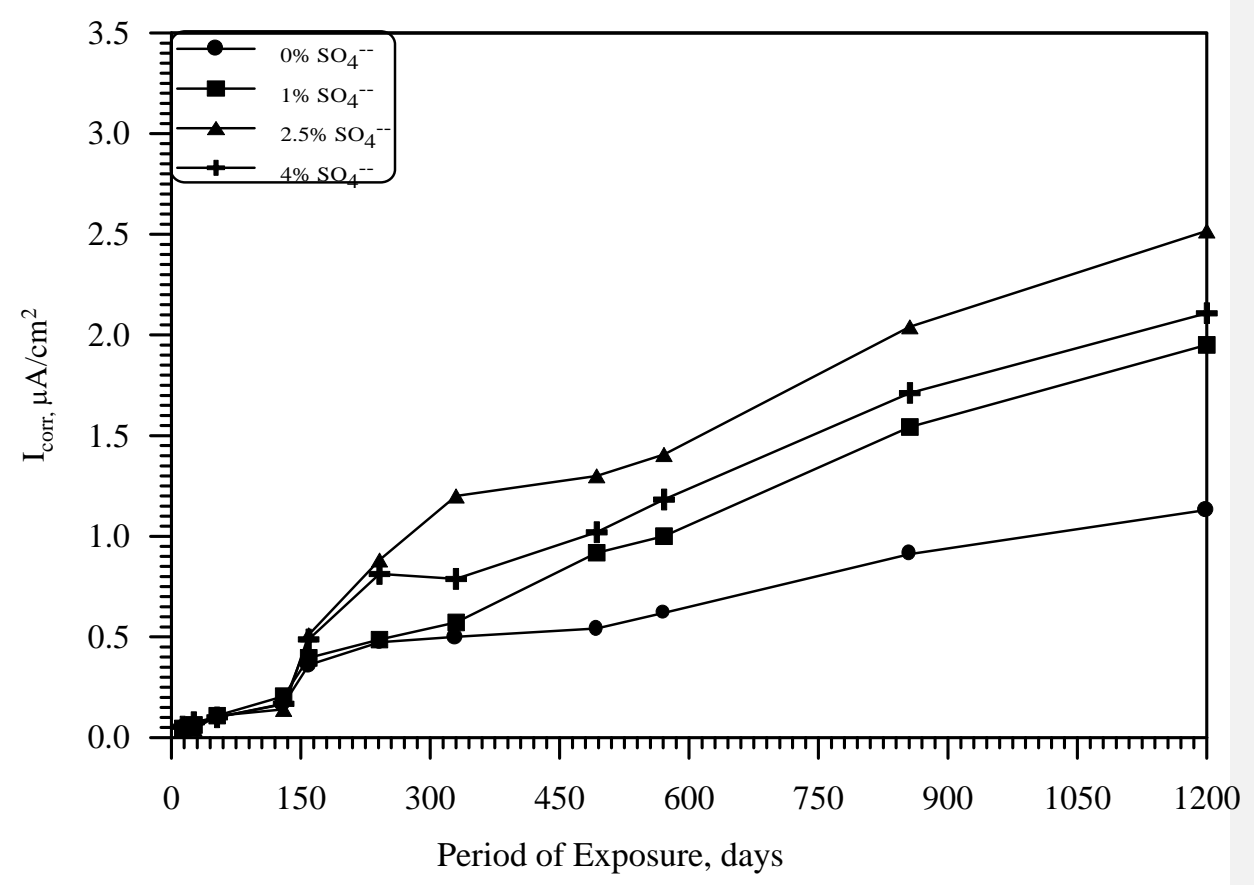

Figure 12: Corrosion current density on steel bars in the OPC-B concrete specimens exposed to $5 \% \mathrm{NaCl}$ plus magnesium sulfate solution. 


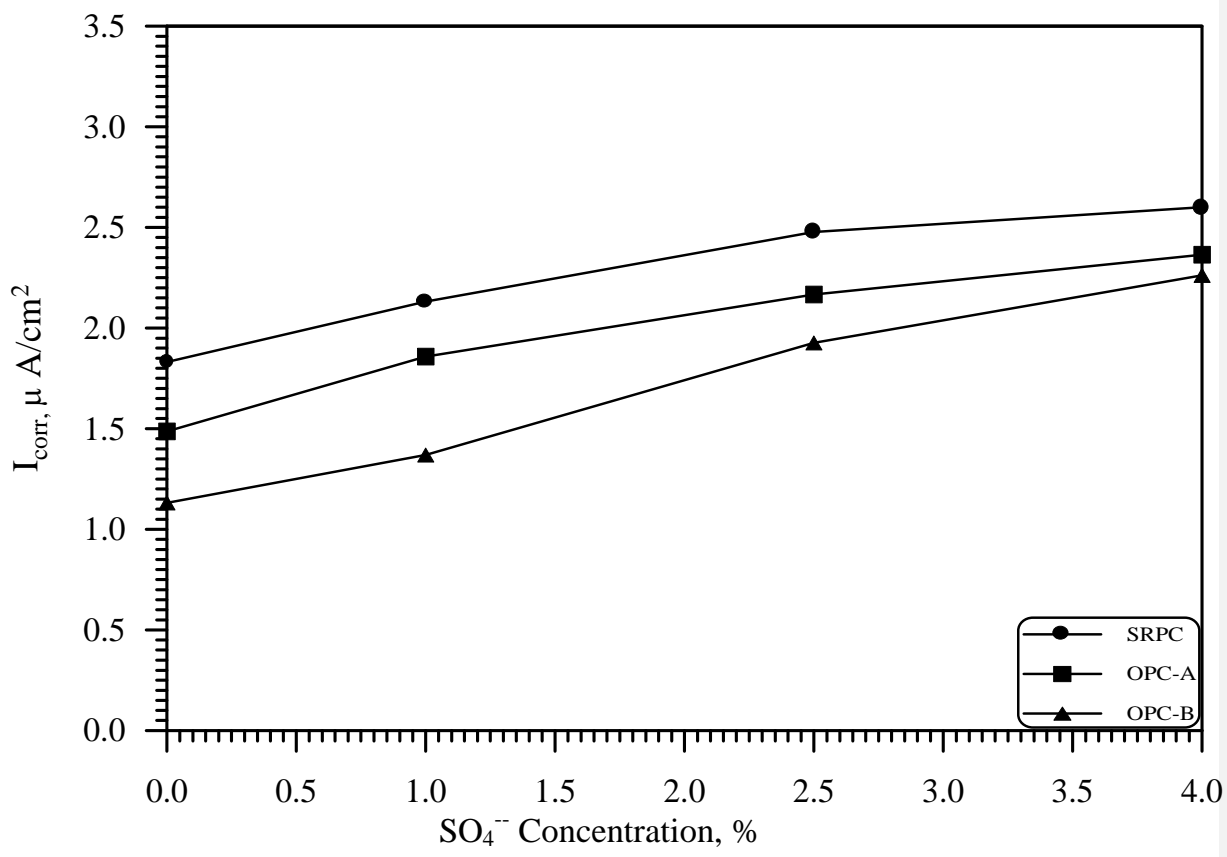

Figure 13: Variation of $\mathrm{I}_{\text {corr }}$ with sulfate concentration in the plain cement concrete specimens exposed to $5 \% \mathrm{NaCl}$ plus sodium sulfate solution.

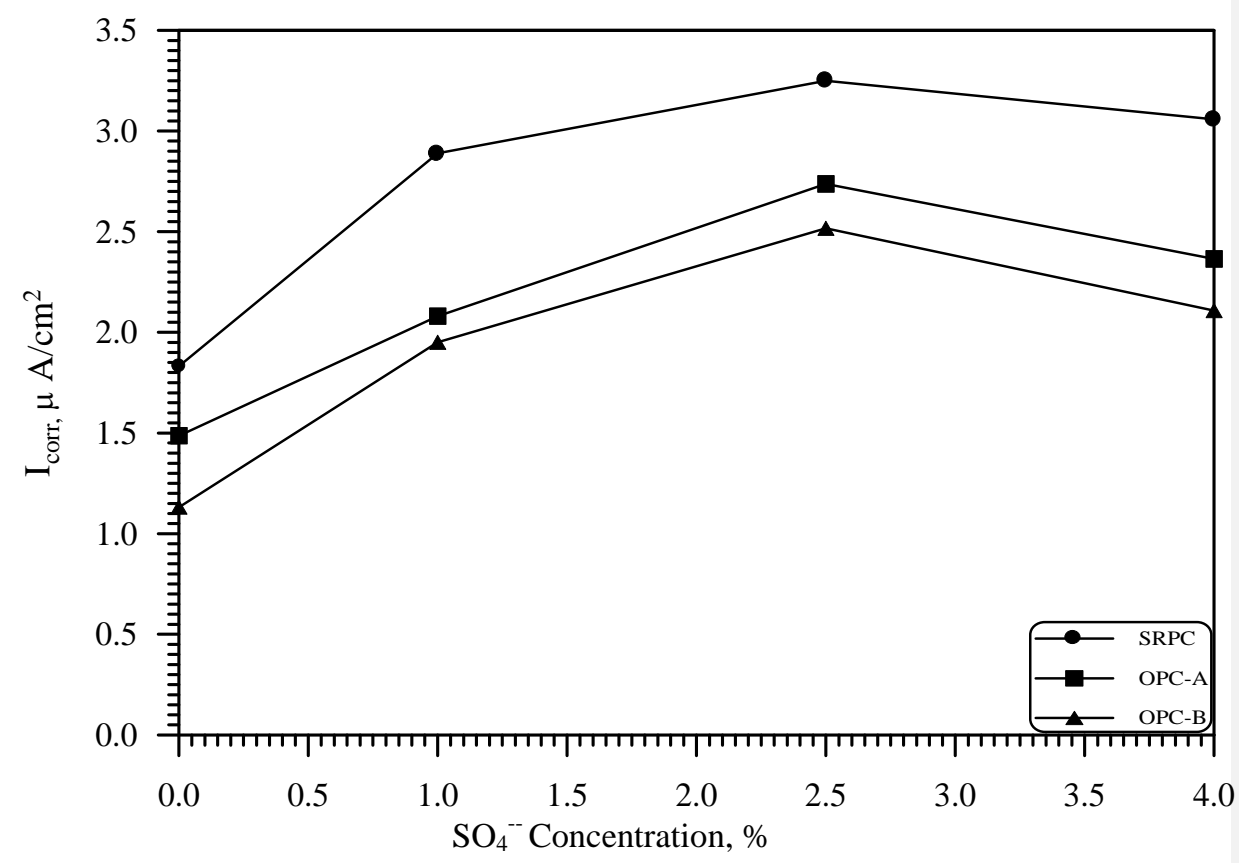

Figure 14: Variation of $\mathrm{I}_{\text {corr }}$ with sulfate concentration in the concrete specimens exposed to $5 \% \mathrm{NaCl}$ plus magnesium sulfate solution. 


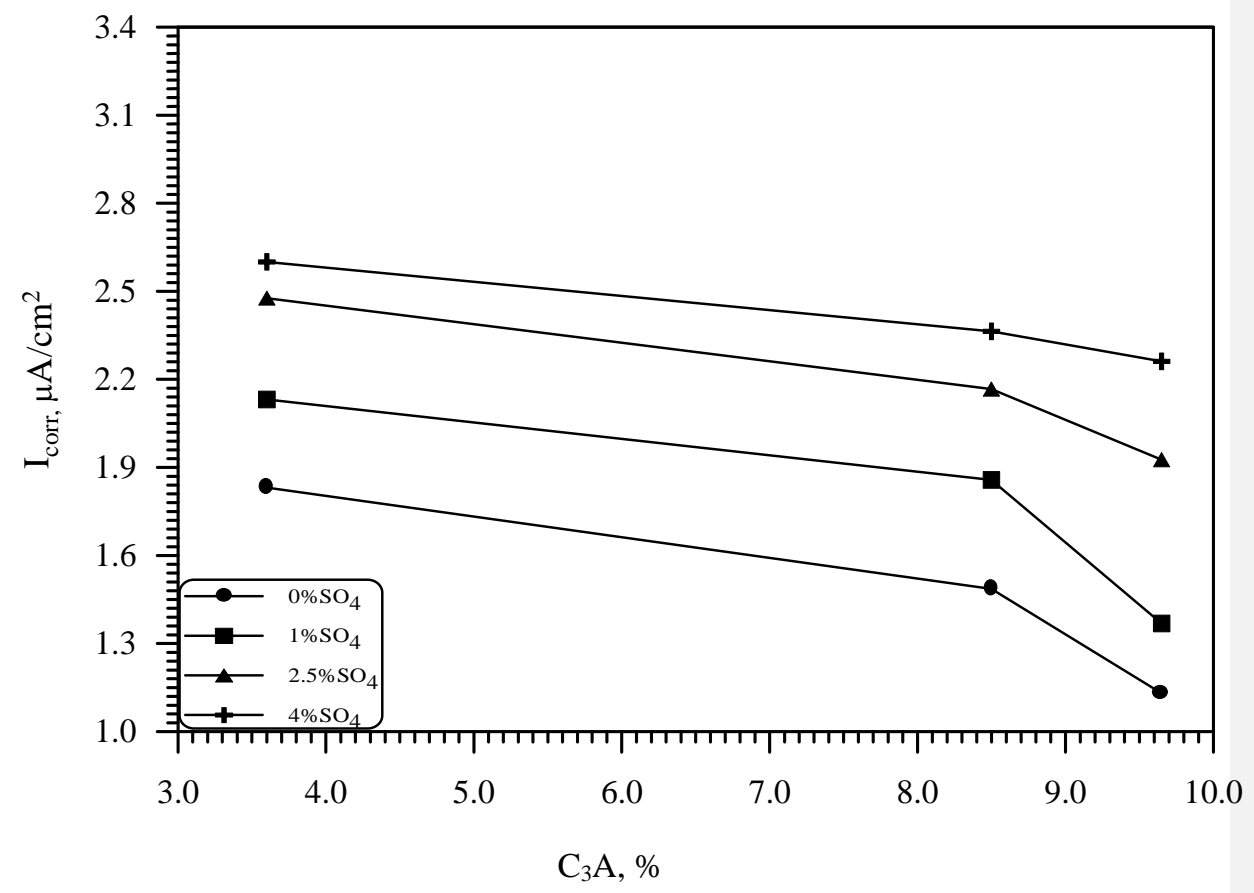

Figure 15: Variation of $\mathrm{I}_{\text {corr }}$ with $\mathrm{C}_{3} \mathrm{~A}$ in the concrete specimens exposed to $5 \% \mathrm{NaCl}$ plus sodium sulfate solution.

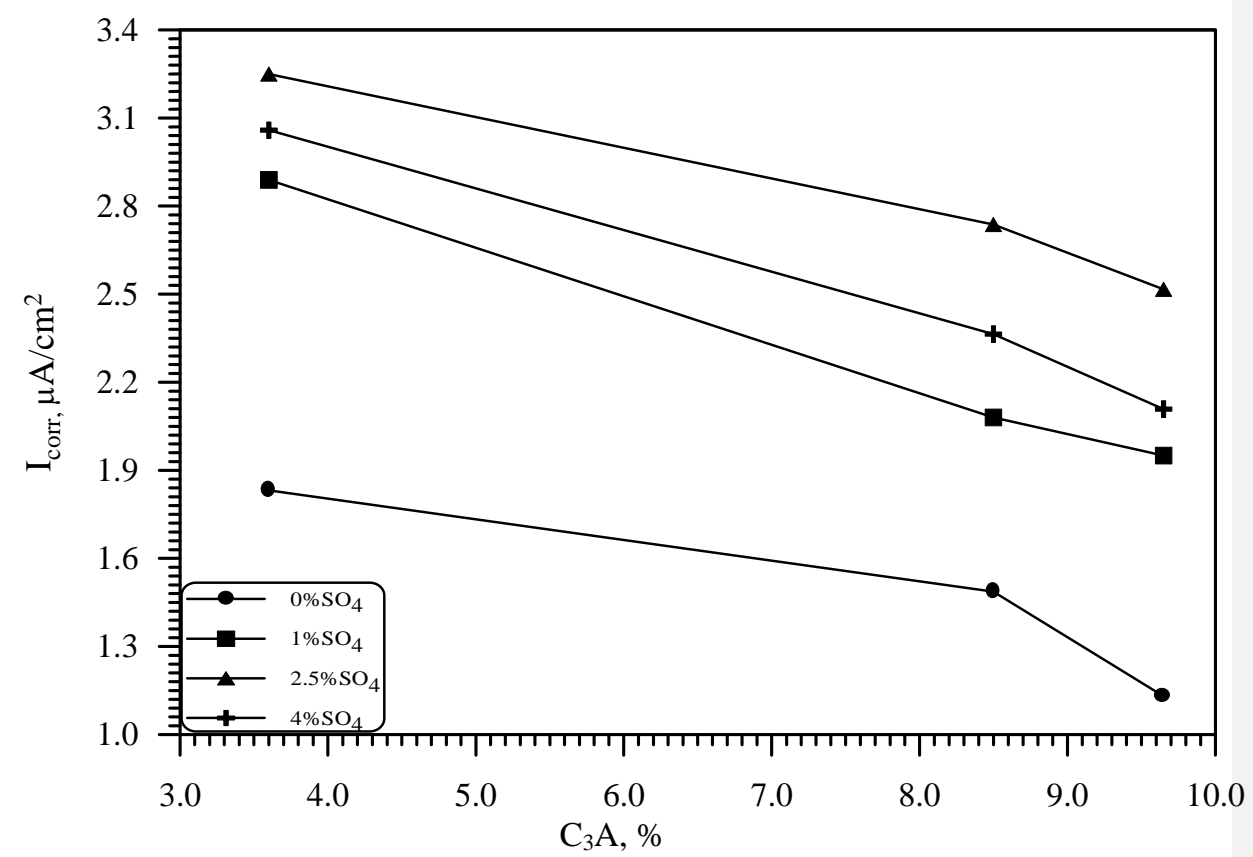

Figure 16: Variation of $\mathrm{I}_{\text {corr }}$ with $\mathrm{C}_{3} \mathrm{~A}$ in the concrete specimens exposed to $5 \% \mathrm{NaCl}$ plus magnesium sulfate solution. 
Table 1: Chemical Composition of cements.

\begin{tabular}{|l|c|c|c|}
\hline Constituent (Wt \%) & SRPC $^{1}$ & OPC-A $^{2}$ & OPC-B $^{3}$ \\
\hline $\mathrm{SiO}_{2}$ & 22.00 & 20.52 & 20.00 \\
\hline $\mathrm{Al}_{2} \mathrm{O}_{3}$ & 4.08 & 5.64 & 6.00 \\
\hline $\mathrm{Fe}_{2} \mathrm{O}_{3}$ & 4.24 & 3.80 & 3.70 \\
\hline $\mathrm{CaO}$ & 64.07 & 64.35 & 65.90 \\
\hline $\mathrm{MgO}$ & 2.21 & 2.11 & 0.70 \\
\hline $\mathrm{SO}_{3}$ & 1.96 & 2.10 & 2.10 \\
\hline $\mathrm{Loss}$ on ignition & 0.80 & 0.70 & 1.30 \\
\hline $\mathrm{K}_{2} \mathrm{O}$ & 0.31 & 0.36 & - \\
\hline $\mathrm{Na}_{2} \mathrm{O}$ & 0.21 & 0.19 & - \\
\hline $\mathrm{Na}_{2} \mathrm{O}$ equivalent & 0.41 & 0.43 & 0.36 \\
\hline $\mathrm{C}_{3} \mathrm{~S}$ & 54.57 & 56.70 & 64.70 \\
\hline $\mathrm{C}_{2} \mathrm{~S}$ & 21.91 & 16.05 & 8.53 \\
\hline $\mathrm{C}_{3} \mathrm{~A}$ & 3.64 & 8.52 & 9.65 \\
\hline $\mathrm{C}_{4} \mathrm{AF}$ & 12.90 & 11.56 & 11.26 \\
\hline
\end{tabular}

1 Sulfate-resisting Portland cement $\left(\mathrm{C}_{3} \mathrm{~A}: 3.6 \%\right)$

2 Ordinary Portland cement $\left(\mathrm{C}_{3} \mathrm{~A}: 8.5 \%\right)$

3.Ordinary Portland cement $\left(\mathrm{C}_{3} \mathrm{~A}: 9.65 \%\right)$ 
Table 2: Composition of the exposure solutions.

\begin{tabular}{|c|c|}
\hline GROUP & Concentration of the test solution \\
\hline 1 & $5 \% \mathrm{NaCl}$ \\
\hline 2 & $5 \% \mathrm{NaCl}+1 \% \mathrm{SO}_{4}^{--}\left(\mathrm{Na}_{2} \mathrm{SO}_{4}\right.$ was used $)$ \\
\hline 3 & $5 \% \mathrm{NaCl}+2.5 \% \mathrm{SO}_{4}^{--}\left(\mathrm{Na}_{2} \mathrm{SO}_{4}\right.$ was used $)$ \\
\hline 4 & $5 \% \mathrm{NaCl}+4 \% \mathrm{SO}_{4}^{--}\left(\mathrm{Na}_{2} \mathrm{SO}_{4}\right.$ was used $)$ \\
\hline 5 & $5 \% \mathrm{NaCl}+1 \% \mathrm{SO}_{4}^{--}\left(\mathrm{MgSO}_{4}\right.$ was used $)$ \\
\hline 6 & $5 \% \mathrm{NaCl}+2.5 \% \mathrm{SO}_{4}^{--}\left(\mathrm{MgSO}_{4}\right.$ was used $)$ \\
\hline 7 & $5 \% \mathrm{NaCl}+4 \% \mathrm{SO}_{4}^{--}$(MgSO \\
\hline
\end{tabular}


Table 3: $\quad$ Time to initiation of reinforcement corrosion in the concrete specimens exposed to sodium chloride plus sodium sulfate or magnesium sulfate solutions.

\begin{tabular}{|c|c|c|c|}
\hline \multirow{2}{*}{ Exposure Solution } & \multicolumn{3}{|c|}{$\begin{array}{l}\text { Time to initiation of } \\
\text { reinforcement corrosion, days }\end{array}$} \\
\hline & SRPC & OPC-A & OPC-B \\
\hline $5 \% \mathrm{NaCl}$ & 118 & 132 & 139 \\
\hline $5 \% \mathrm{NaCl}+1 \% \mathrm{SO}_{4}^{--}\left(\mathrm{Na}_{2} \mathrm{SO}_{4}\right)$ & 113 & 117 & 119 \\
\hline $5 \% \mathrm{NaCl}+2.5 \% \mathrm{SO}_{4}^{--}\left(\mathrm{Na}_{2} \mathrm{SO}_{4}\right)$ & 137 & 146 & 148 \\
\hline $5 \% \mathrm{NaCl}+4 \% \mathrm{SO}_{4}^{--}\left(\mathrm{Na}_{2} \mathrm{SO}_{4}\right)$ & 119 & 133 & 131 \\
\hline $5 \% \mathrm{NaCl}+1 \% \mathrm{SO}_{4}^{--}\left(\mathrm{MgSO}_{4}\right)$ & 111 & 115 & 114 \\
\hline $5 \% \mathrm{NaCl}+2.5 \% \mathrm{SO}_{4}^{--}\left(\mathrm{MgSO}_{4}\right)$ & 116 & 126 & 131 \\
\hline $5 \% \mathrm{NaCl}+4 \% \mathrm{SO}_{4}^{--}\left(\mathrm{MgSO}_{4}\right)$ & 127 & 137 & 141 \\
\hline
\end{tabular}

